\title{
The Jewish Tradition - Does It Matter?
}

T he Jewish Tradition - Does It Matter? This was the title given to a seminar arranged at the University of Oslo, 4-5 March 2018, gathering Nordic scholars from different research fields as well as a wider audience including members of the local Jewish community for two days of discussion and exchange. Professor Catherine Hezser from SOAS University in London, who is currently also Professor II of Jewish Studies in Oslo, was the main organiser of the seminar, whose purpose was 'to explore the relevance of the Jewish tradition (Torah, rabbinic tradition, rituals) as it developed from ancient times until today, for both Jews and non-Jews in Norway and other Scandinavian countries'. In this section of the journal, we are happy to be able to publish three of the presentations given at the seminar, by Ruth Illman, Walter Homolka and Tyson Herberger.

Five keynote lectures were presented at the conference. In addition to the lectures by Illman and Homolka, which are published in this issue, Professor Marianne Schleicher (Aarhus University) lectured 'On the function of the Hebrew Bible for gender norms in western Judaism', Professor Catherine Hezser on 'Judaism as embodied religion: the rabbinic focus on material existence and daily life' and Professor Karin Hedner Zetterholm on 'These and these are the words of the living god: the value of study and debate in the Jewish tradition'. In addition, a lively and well-attended panel discussion was arranged at the Jewish Museum in Oslo, focusing on the theme 'Jews and Judaism in Norway today'. The panel included rabbis Lynn Feinberg of the Jewish Renewal Movement, Tyson Herberger of the Orthodox movement, Joav Melchior of the Orthodox movement and the current rabbi of the Jewish community in Oslo, and Shaul Wilhelm of the Habad movement. Rabbi Herberger's article in this issue is based on his contribution to this panel.

In addition, the seminar also included an informative and memorable walking-tour of Jewish Oslo, which took the participants on a sunny early Sunday morning walk through the snow-clad streets where the Jewish presence in Oslo has been the most prominent over the centuries. In all, the seminar provided an important forum to discuss Jewish studies in the Nordic countries today and will hopefully serve to strengthen the networks in the field.

\section{RUTH ILLMAN}

More information about the seminar is found at: <https://www.tf.uio.no/english/about/newsand-events/events/2018/jewish-tradition.html> 